Eawag_05742

Limnol. Oceanogr., 54(6), 2009, 22432254

(C) 2009, by the American Society of Limnology and Oceanography, Inc.

\title{
Organic carbon burial efficiency in lake sediments controlled by oxygen exposure time and sediment source
}

\author{
Sebastian Sobek, ${ }^{a, b,{ }^{*}}$ Edith Durisch-Kaiser, a,b Roland Zurbrügg,a,b Nuttakan Wongfun, ${ }^{\text {a,c }}$ \\ Martin Wessels, ${ }^{\mathrm{d}}$ Natacha Pasche, ${ }^{\mathrm{a}, \mathrm{b}}$ and Bernhard Wehrlia,b \\ ${ }^{a}$ Eawag, Swiss Federal Institute of Aquatic Science and Technology, Kastanienbaum, Switzerland \\ ${ }^{\mathrm{b}}$ Eidgenössische Technische Hochschule (ETH), Swiss Federal Institute of Technology Zürich, Institute of Biogeochemistry and \\ Pollutant Dynamics, Zürich, Switzerland \\ ${ }^{c}$ United Nations Educational, Scientific and Cultural Organization (UNESCO) International Institute for Hydraulic and Environmental \\ Engineering (IHE), Institute for Water Education, Delft, The Netherlands \\ dInstitute for Lake Research, Langenargen, Germany
}

\begin{abstract}
We compared the burial efficiency of organic carbon (buried OC: deposited OC) in a diverse set of 27 different sediments from 11 lakes, focusing on the potential effects of organic matter source, oxygen exposure, and protective sorption of OC onto mineral surfaces. Average OC burial efficiency was high (mean 48\%), and it was particularly high in sediments receiving high input of allochthonous organic matter (mean 67\%). Further, OC burial efficiency was strongly negatively related to the oxygen exposure time, again particularly so in sediments receiving high allochthonous loads. On the other hand, OC burial efficiency was not related to the mineral surface area, which was used as a proxy of the sorption capacity of the mineral phase for OC. The high OC burial efficiency in many lake sediments can thus be attributed to the frequent and significant input of allochthonous organic matter to lakes, as well as to a strong dependence of $\mathrm{OC}$ burial efficiency on oxygen exposure time. This study demonstrates that the carbon sink in lake sediments alters the OC export from the continents to the sea and that the fate of $\mathrm{OC}$ in lake sediments (burial vs. mineralization to carbon dioxide and methane) is highly sensitive to environmental conditions.
\end{abstract}

Organic carbon (OC) that is deposited onto the surface of a sediment will either be mineralized to $\mathrm{CO}_{2}$ or $\mathrm{CH}_{4}$ by heterotrophic microbes or it will be buried in the sediments over geological timescales. OC burial in sediments is an important sink in the global carbon cycle, removing carbon from the actively cycling carbon pools. Compared to other fluxes in the global carbon cycle, OC burial constitutes a small flux (about $0.1 \mathrm{Pg} \mathrm{C}$ yr 1 in marine sediments; IPCC 2007), but it has lead to the accumulation of vast stocks of fossil carbon. Accordingly, substantial research efforts in oceanography have been directed toward a mechanistic understanding of the factors governing $\mathrm{OC}$ burial in marine sediments (Burdige 2007).

Studies on accumulation of OC in lakes, on the other hand, have been more fragmented, and the rates of OC burial reported from different lakes differ by more than two orders of magnitude (Mulholland and Elwood 1982; Kortelainen et al. 2004; Downing et al. 2008). Dean and Gorham (1998) estimated that the annual OC burial in lake sediments could amount to about $50 \%$ of the annual OC burial in marine sediments. Considering that lakes cover only about $2 \%$ of Earth's surface, as compared to $71 \%$ covered by ocean, it becomes evident that lake sediments represent a very efficient sink in the global carbon cycle. However, the reasons for this highly efficient OC burial in lake sediments are poorly understood. Two studies report relationships between OC burial and a number of lake and sediment characteristics (Håkanson 2003; Alin and John-

\footnotetext{
*Corresponding author: sebastian.sobek@env.ethz.ch
}

son 2007) but provide no explanations of the mechanisms responsible for the efficient OC burial in lake sediments. Similarly, a recent study by Downing et al. (2008) demonstrated very high OC burial in small impoundments such as farm ponds, but the mechanisms responsible for this high OC burial remain unclear. Due to this lack of mechanistic understanding, it is presently impossible to gauge the response of $\mathrm{OC}$ burial in lake sediments to climate change.

Extensive studies on marine sediments have identified a wide array of different factors that may contribute to the preservation of OC in sediments, such as primary production rate, chemical composition of organic matter, sediment accumulation rate, bottom water oxygen concentration, the availability of electron acceptors, characteristics of the microbial decomposers, mixing by macrobenthos, oscillations in redox potential, and sorption on inorganic particles (Hedges et al. 1999). Many of these factors are interdependent, and their relative importance is likely to shift with time and space. The mechanisms that have received most attention in marine sediments are oxygen exposure, protective sorption onto mineral surfaces, and the chemical composition of the organic matter (Burdige 2007).

Several different studies have shown that anoxia favors OC preservation and the formation of oil precursors in marine sediments (Demaison and Moore 1980; Gelinas et al. 2001). The oxygen exposure time (OET) has been found to act as a major regulator of OC preservation in marine sediments (Hartnett et al. 1998; Hedges et al. 1999), as it 
integrates several environmental factors that are related to OC burial (oxygen concentration, primary productivity, sedimentation rate). There are indications that in lake sediments as well, long oxygen exposure time may favor the extent of OC mineralization, thereby lowering OC burial (Märki et al. 2006).

Organic matter can adsorb onto the surfaces of mineral particles, which limits or inhibits mineralization rates in marine sediments (Keil et al. 1994; Mayer 1994b). There is evidence that sorption onto mineral surfaces, storage in meso-sized pores of mineral particles, and association with amorphous metal oxides all contribute to the physical protection of organic matter against attacks by microbial exoenzymes (Burdige 2007). Accordingly, a model based solely on the physical protection of organic matter by mineral particles could explain the empirically observed OC decay rates in marine sediments (Rothman and Forney 2007). In soils and sediments, the surface area of minerals is positively related to the OC concentration (Mayer 1994a), and it may therefore be regarded as an indicator of the extent of protective sorption of OC on minerals. Also for lake sediments, there are indications that protective sorption onto mineral surfaces can contribute to the preservation of OC (Laskov et al. 2002).

The fate of organic matter in sediments is ultimately determined by its chemical composition, i.e., its molecular structure (Westrich and Berner 1984). Several studies have demonstrated that allochthonous (i.e., land plant derived) compounds, as well as microbial membrane remnants, are prone to selective preservation in marine sediments (Burdige 2007). Autochthonous (i.e., internally produced) organic matter, on the other hand, is comparatively easily decomposed by heterotrophic microbes, and thus it is less prone to accumulation in sediments (Burdige 2007). A few studies have hinted that similar mechanisms are also valid for lacustrine ecosystems (Cranwell 1981; Ho and Meyers 1994), and hence the organic matter source may profoundly affect OC burial in lake sediments.

The relative importance of oxygen exposure time, sorption onto mineral surfaces, and organic matter source for OC burial in lake sediments has to date not been studied systematically. Here, we compare a set of different lake sediments, varying widely in oxygen exposure time, mineral surface area, and organic matter source, in order to better understand the mechanisms behind the effective OC burial in lake sediments. We show that oxygen exposure time and organic matter source are important regulators of OC burial in lake sediments, while organic matter sorption on mineral surfaces plays a subordinate role.

\section{Methods}

Site selection We chose sampling sites for lake sediments representing end members of gradients in oxygen exposure time, mineral phase properties, and organic matter source (Table 1). While we collected quantitative data on the oxygen exposure time and the mineral surface area, the dominating source of organic matter was derived from the literature and resulted in a qualitative grouping into sediments dominated by autochthonous organic matter, and sediments dominated by allochthonous organic matter.

The three Swedish boreal lakes (Svarttjärn, Gäddtjärn, and Lilla Sångaren) are oligotrophic, humic-rich systems, and the sediments are dominated by allochthonous organic matter (Von Wachenfeldt and Tranvik 2008). These lakes are small $\left(0.007,0.07\right.$, and $0.24 \mathrm{~km}^{2}$ for Svarttjärn, Gäddtjärn, and Lilla Sångaren, respectively) and shallow, and only one site was sampled within each of the three lakes (Table 1). Lake Baikal $\left(31,494 \mathrm{~km}^{2}\right)$ is the world's largest lake by volume and very oligotrophic, and the sediments of Lake Baikal are the most highly oxygenated lake sediments reported in the literature (Martin et al. 1998). Five sites were selected in Lake Baikal. While the Posolskaya site receives some input of allochthonous organic matter and riverine particles from the Selenga River, the sediments of the four other sites receive predominantly internally produced material (Müller et al. 2005). In oligotrophic Lake Constance $\left(539 \mathrm{~km}^{2}\right)$, we sampled four sites along a gradient of riverine input from the Rhine River, draining the Alps (Wessels 1998). The site closest to the Rhine River inflow receives almost exclusively allochthonous matter, while at the south shore of the central basin, sediments consist predominantly of autochthonous material. In the north basin of eutrophic Lake Zug $\left(38.3 \mathrm{~km}^{2}\right)$, we sampled two sites at different depths, which are characterized by different bottom water oxygen regimes. Due to high internal production and limited riverine inflow, sediments of this basin are mainly derived from internal production (Meckler et al. 2004). Lake Wohlen $\left(2.5 \mathrm{~km}^{2}\right)$ is a mesotrophic reservoir in the Aare River with an average water retention time of roughly $2 \mathrm{~d}$ (Albrecht et al. 1998); it consequently receives high riverine input. We sampled Lake Wohlen at five sites along a transect from the dam (WO-A) to the inflow area (WO-H). Ultra-oligotrophic alpine Lake Brienz $\left(29.8 \mathrm{~km}^{2}\right)$ receives high particle loads from tributaries fed by upstream glaciers, and the deep site $(210 \mathrm{~m})$ receives a higher particle load than the shallow site (20 m) (Müller et al. 2007). Lake Lugano $\left(48.7 \mathrm{~km}^{2}\right)$ is eutrophic, resulting in the sediment being mainly derived from autochthonous sources. A certain proportion of allochthonous matter is present in the sediment, derived from tributaries draining the alpine catchment (Hofmann 1996). The north basin of Lake Lugano has been meromictic during the past $40 \mathrm{yr}$, implying that the sediments were deposited under permanently anoxic conditions. In eutrophic Lake Kinneret $\left(166 \mathrm{~km}^{2}\right)$, three shallow sites with increasing distance from the Jordan River inflow were sampled, and one site was sampled in the middle of the lake, where the sediments are anoxic for about 6 months per year. Sediments in Lake Kinneret are primarily derived from internal production and have a variable, but small degree of allochthonous input from the Jordan River (Koren and Klein 2000). Lastly, tropical Lake Kivu (2370 $\mathrm{km}^{2}$ ) is a eutrophic lake with permanently anoxic bottom waters. The sediments of Lake Kivu are mainly formed by autochthonous material (Al-Mutlaq et al. 2008).

Sampling For Lakes Baikal, Zug, Brienz, and Lugano, published data on OC burial, OC mineralization, and oxygen pore-water profiles were available (Table 1). The 


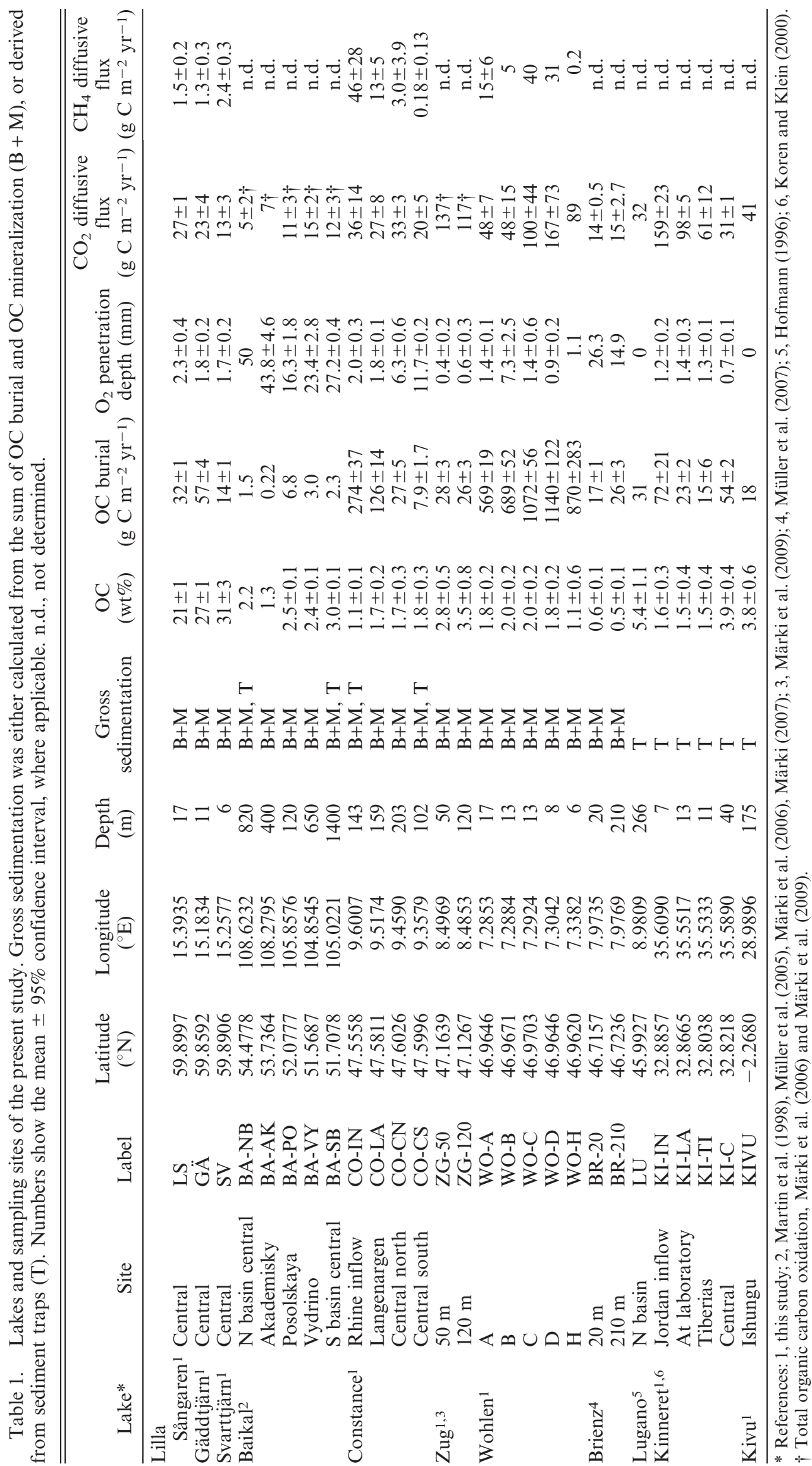


sediments of the other lakes were sampled with a gravity corer, resulting in $\sim 30100-\mathrm{cm}$-long sediment cores. One core from each site was sliced at $0.52-\mathrm{cm}$ intervals, depending on the expected sedimentation rate. These samples were then analyzed for bulk sediment properties (water content, elemental composition, mineral surface area). An additional 23 cores were taken at each site for the measurement of the oxygen penetration depth using microsensors, as described in the following section. These cores were stored in the dark until measurement, and care was taken to minimize temperature change. Furthermore, 2 3 cores equipped with side ports were taken at each site in order to sample methane in the sediment pore-water. Sampling was repeated in order to cover seasonal variations in oxygen and methane pore-water concentrations. Lake Wohlen was sampled three times at the site closest to the dam (WO-A), and once along the riverine input gradient. The other lakes (Swedish boreal lakes, Lake Constance, Lake Kinneret) were sampled twice (Table 1). Lake Kivu was sampled once as described already, but due to permanently anoxic bottom waters, no cores for the measurement of oxygen profiles were taken.

Pore-water analyses Profiles of oxygen concentration in the sediment pore-water were measured using oxygen micro-optodes (tip size $<50 \mu \mathrm{m}$; PreSens) mounted on a computer-controlled micromanipulator (Newport), which moved the micro-optodes vertically in step sizes of 0.10 .2 $\mathrm{mm}$. Measurement commenced usually $14 \mathrm{~h}$ after retrieving the core; hence, bottom water oxygen concentrations were probably similar to in situ conditions. For measurement, most of the water overlying the sediment was carefully siphoned off, leaving about $5 \mathrm{~cm}$ of water column above the sediment. In each core, three oxygen profiles were recorded. Measurements were conducted as close to in situ temperature as possible; occasionally observed moderate temperature increases during measurement are not expected to have affected the measured profiles to any large extent during the short time of measurement. The similarity of diffusive boundary layer thickness observed in the cores (mean $\pm \mathrm{SD}, 0.64 \pm 0.32 \mathrm{~mm}$ ) with values typically reported from benthic lander measurements of lake sediments (range $0.21 \mathrm{~mm}$; Märki et al. 2009) indicates that the artificial turbulence conditions inside the core did not seem to have any major effect on our estimates of oxygen flux across the sediment water interface. The oxygen sensors were calibrated using water-saturated air and an oxygen-free solution $(1: 1$ mixture of $0.1 \mathrm{~mol} \mathrm{~L} 1$ sodium ascorbate and $\left.0.1 \mathrm{~mol} \mathrm{~L}{ }^{1} \mathrm{NaOH}\right)$. Analytical precision was $\pm 0.5 \%$. The oxygen penetration depth was calculated as the difference in distance between the sediment water interface (defined from the shape and the standard deviations of the oxygen profile; Archer et al. 1989) and the depth of onset of anoxia.

Samples for the measurement of dissolved $\mathrm{CH}_{4}$ in sediment pore-water were taken using a core liner with side ports (1-cm distance between ports). From each core, eight samples were taken, covering between 0 and $15 \mathrm{~cm}$ of sediment depth. From each layer, $2 \mathrm{~mL}$ of sediment were extracted through a side port using a plastic syringe with a cut-off tip, and transferred to a $25-\mathrm{mL}$ glass vial prefilled with $4 \mathrm{~mL}$ of $2.5 \% \mathrm{NaOH}$. The vial was sealed immediately using a gas-tight butyl-rubber stopper and an aluminum crimp seal, shaken, and then stored upside down until analysis. Quantification of $\mathrm{CH}_{4}$ was accomplished by injecting $500 \mu \mathrm{L}$ of equilibrated headspace from the glass vials into a Carlo Erba HRGC 5160 gas chromatograph equipped with a J\&W GSQ column $(30 \mathrm{~m} \times 0.53 \mathrm{~mm})$ and a flame ionization detector (FID). Known amounts of standard gas (Scotty, Supelco) were injected in quadruplicate and served for quantification. Analytical precision was $\pm 5 \%$.

Sediment analyses Water content of the sediment was measured by weighing samples both wet and after freeze drying. Contents of total carbon and nitrogen were measured by high-temperature catalytic oxidation using a LECO CHNS-932. Inorganic carbon concentrations were measured on a coulometer after acidification with $2 \mathrm{~mol}$ $\mathrm{L} 1$ perchloric acid (UIC). The organic carbon (OC) content was then calculated as the difference between total and inorganic carbon. Analytical precision was $\pm 1 \%$.

Dry bulk density $(\rho)$ of the sediment was calculated from the OC content (Müller et al. 2005), assuming that the sediment is a two-phase mixture between silicate and carbonate minerals (density about $2.65 \mathrm{~g} \mathrm{~cm}^{3}$ ) and organic matter (density about $1 \mathrm{~g} \mathrm{~cm}^{3}$ ):

$$
\rho\left(\mathrm{g} \mathrm{cm}^{3}\right)=-0.0523 \times \mathrm{OC}(\%)+2.65
$$

We also measured the dry bulk density in 45 samples from different sediments using a pycnometer. The difference between calculated and measured density was on average $4 \%$ and did not affect the estimates of OC burial.

From bulk dry density $\left(\rho, \mathrm{g} \mathrm{cm}^{3}\right)$ and water content $(w c, \%)$, we then calculated porosity $(\Phi)$ as follows:

$$
\Phi=\frac{w c}{(w c+(1-w c) \cdot \rho)}
$$

The mineral surface area (MSA) was determined by means of $\mathrm{N}_{2}$ adsorption at $196^{\circ} \mathrm{C}$ on a Sorptomatic 1990 (Thermo Electron Corporation), according to the BET method (named after Brunauer, Emmett, and Teller 1938). Organic matter was removed by thermal oxidation at $350^{\circ} \mathrm{C}$ for $12 \mathrm{~h}$ (Mayer 1999). To remove water vapor prior to adsorption analysis, each sample was evacuated at $100^{\circ} \mathrm{C}$ until pressure was $<0.02 \mathrm{~Pa}$, and then evacuated at $100^{\circ} \mathrm{C}$ for another $2 \mathrm{~h}$. For calculation of BET parameters, six points within the linear part (relative pressure $\left[p: p_{0}\right] 0.05$ 0.3 ) of the adsorption isotherm were used. MSA at sites in lakes Baikal and Brienz was measured on archived sediment samples.

Sedimentation rates were determined from depth profiles of ${ }^{210} \mathrm{~Pb}$ and/or ${ }^{137} \mathrm{Cs}$, analyzed by gamma spectrometry using germanium detectors (Canberra). The sedimentation rate was corrected for compaction of sediment according to $\mathrm{Lu}$ (2007). At some sites with very heterogeneous sedimentation regime in lakes Constance and Wohlen, the depth profiles of ${ }^{137} \mathrm{Cs}$ and/or ${ }^{210} \mathrm{~Pb}$ could not be used for dating. 
At the site close to the inflow of the Rhine River in Lake Constance (CO-IN), the sedimentation rate was determined from the depth difference of a stratigraphic marker (the August 2005 extreme flood event) at two consecutive years. In Lake Wohlen, sedimentation rates were derived from water-depth surveys conducted by the hydropower company (BKW FMB Energie) in 1990 and 2004. The difference in standardized water depth between 1990 and 2004 represents the sedimentation rate during this period. For each of the coring sites, the sedimentation rates of two to four nearby depth-survey locations were averaged to represent the sedimentation rate of the coring site.

Calculations The burial efficiency of organic carbon (OC BE, \%) was calculated as the ratio between OC burial (i.e., mean mass accumulation rate in the sediment, $\mathrm{g} \mathrm{C}$ $\mathrm{m}^{2} \mathrm{yr}^{1}$ ) and $\mathrm{OC}$ gross sedimentation (i.e., mean mass deposition rate onto the sediment surface, $\mathrm{g} \mathrm{C} \mathrm{m}^{2} \mathrm{yr}^{1}$ ). Gross sedimentation was either derived from sediment traps, if such data were available, or calculated as the sum of OC burial and OC mineralization (Table 1). OC mineralization ( $\mathrm{g} \mathrm{C} \mathrm{m}^{2} \mathrm{yr}{ }^{1}$ ) was calculated from porewater profiles of oxygen and methane using Fick's first law of diffusion. The methane profiles observed in this study generally exposed a strong quasi-linear decrease of methane concentrations over the top 4 or $5 \mathrm{~cm}$ of sediment, probably induced by intense methane oxidation at the oxic anoxic boundary (data not shown). Methane fluxes were calculated over this gradient and therefore include methane oxidation. Oxygen fluxes were converted to carbon dioxide fluxes by using a respiratory quotient of 0.9 (Granéli 1979), and total OC mineralization was then calculated as the sum of $\mathrm{CO}_{2}$ and $\mathrm{CH}_{4}$ flux from the sediment to the water column. Oxygen exposure time was calculated by dividing the mean oxygen penetration depth by the sedimentation rate.

Statistics We used partial least squares regression (PLS; Höskuldsson 1988) in order to determine the way different variables perform as predictors of OC burial efficiency. A PLS regression places uncorrelated latent components (i.e., orthogonal axes) into the $X$ data space in order to maximally explain the variability in the $Y$ data. Compared to ordinary multiple linear regression, PLS is relatively insensitive against the interdependence of $X$ variables on each other, and against deviations from normality. Also, the PLS algorithm is very tolerant to missing values. The performance of the PLS model is expressed in the terms $R^{2} Y$ and $Q^{2} . R^{2} Y$ is comparable to $R^{2}$ in linear regression, and $Q^{2}$ is a measure of the predictive power of the model. Using a permutation test, $R^{2} Y$ was corrected for the intrinsic "background correlation" of the data, i.e., the baseline in $R^{2} Y$ that is not indicative for any correlations between variables, but is only due to chance. Highly skewed variables (skewness $>$ 2.0 and $\min : \max$ ratio $<0.1)$ were logarithmically transformed prior to modeling in order to increase model performance. All PLS modeling was done on the SIMCA$\mathrm{P}+12.0$ software (Umetrics).

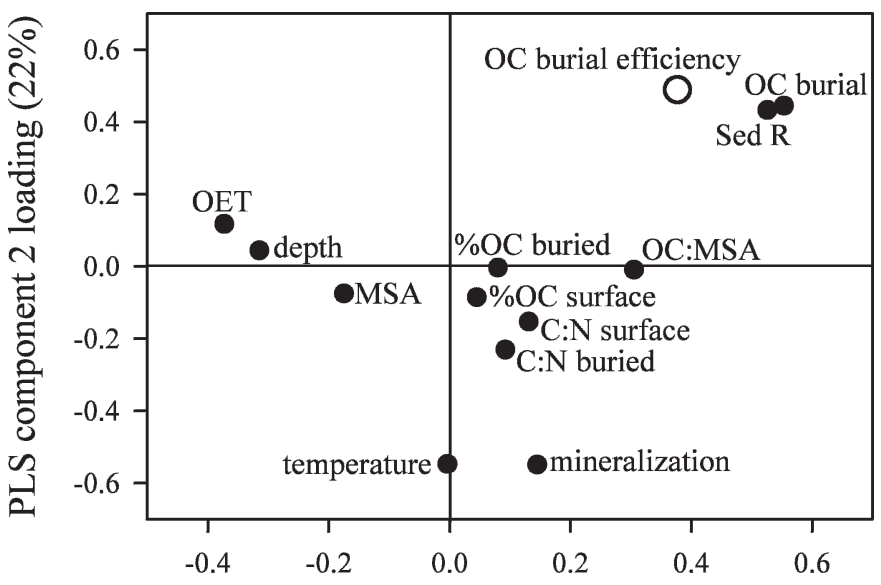

PLS component 1 loading (60\%)

Fig. 1. Partial least squares regression (PLS) loadings plot, depicting the relationships between the different $X$ variables (closed circles) and OC burial efficiency (open circle). The model explains $84 \%$ of the variability in OC burial efficiency; when corrected for background correlation, the degree of explanation is $68 \%$. Variables situated along the same directional axis correlate positively with each other; variables situated at opposite ends of the plot correlate negatively with each other; variables situated in the center of the plot are poor predictors of OC burial efficiency. The horizontal axis explains about three times as much of the variability in OC burial efficiency as compared to the vertical axis. Abbreviations are as follows: OET, oxygen exposure time; MSA, mineral surface area; Sed R, linear sedimentation rate.

\section{Results}

In the studied 27 lake sediments, OC burial ranged between 0.2 and $1140 \mathrm{~g} \mathrm{C} \mathrm{m}^{2} \mathrm{yr}^{1}$ (median 27, mean $192 \mathrm{~g}$ $\mathrm{C} \mathrm{m} 2 \mathrm{yr}^{1}$ ), and OC mineralization ranged between 5.3 and $196 \mathrm{~g} \mathrm{C} \mathrm{m}^{2} \mathrm{yr}^{1}$ (median 40, mean $58 \mathrm{~g} \mathrm{C} \mathrm{m}^{2} \mathrm{yr}^{1}$ ). Consequently, organic carbon burial efficiencies (OC BE; OC burial:OC deposition, see Methods section) varied greatly, covering a range from $3 \%$ to $93 \%$ (median and mean, 48\%). Oxygen penetration depths in the sediments overlain by oxygenated water varied between 0.4 and $>50$ $\mathrm{mm}$, and sedimentation rates covered over three orders of magnitude $\left(0.0279 \mathrm{~mm}\right.$ yr $\left.{ }^{1}\right)$. This resulted in oxygen exposure times (OET) ranging from essentially zero in lakes with permanently anoxic bottom waters to $>2000 \mathrm{yr}$ at Akademisky Ridge in Lake Baikal (median OET $0.5 \mathrm{yr}$, mean $93 \mathrm{yr}$ ). Also, the mineral surface area (MSA) was variable among the different lake sediments; values were between 5.7 and $86 \mathrm{~m}^{2} \mathrm{~g}{ }^{1}$ (median 21.6, mean $30.3 \mathrm{~m}^{2}$ g ${ }^{1}$ ). Hence, the broad diversity of lake sediments included in this analysis ensures that general conclusions can be drawn regarding the influence of OET and MSA on OC BE.

The partial least squares regression (PLS) explained a significant fraction of the variability in OC BE between sites $\left(R^{2} Y=0.83 ; R^{2} Y_{\text {corrected }}=0.68 ; Q^{2}=0.69\right)$ and provided a comprehensive overview of the correlation structures in our data set (Fig. 1). The results of the PLS analysis show the importance of the different $X$ variables in explaining the $Y$ 
variable (i.e., $\mathrm{OC} \mathrm{BE}$ ), and the relationships of the $X$ variables with each other. Variables are positively correlated if they plot close to each other, while they are negatively correlated if they are placed at opposite ends of the plot. Variables in the center of the plot are at most poorly related to the variables at the outer ends of the plot area. The first component (horizontal axis in Fig. 1) explained roughly three times as much of the variance in the data set as the second component (vertical axis in Fig. 1), and it is therefore of higher importance when interpreting the plot.

The OC BE was strongly positively correlated with OC burial and the sedimentation rate (Fig. 1). Also, the $\mathrm{OC}$ : MSA ratio, expressing the organic loading of the mineral surface area, was positively related to $\mathrm{OC} \mathrm{BE}$. On the other hand, OET and water depth were negatively related to OC BE (along the first component), as well as OC mineralization and annual mean bottom water temperature (along the second component). The $\mathrm{OC}$ concentration, the molar $\mathrm{C}: \mathrm{N}$ ratio, and the MSA were at most weakly related to OC BE.

A closer look at the negative relationship between OET and OC BE revealed that the different lake sediments followed two different relationships (Fig. 2). Sediments that receive significant input of autochthonous material (BA-AK, BA-SB, BA-NB, BA-VY, KI-LA, KI-TI, ZG-50, ZG-120, LU and KIVU; see Table 1) grouped around the OET OC BE regression line for marine sediments reported by Hartnett et al. (1998). Sediments that receive a significant input of allochthonous material followed a different relationship with steeper slope $(\mathrm{OC} \mathrm{BE}=16.7$ $\left.\times \log [\mathrm{OET}]+61.2 ; R^{2}=0.81 ; p<0.0001 ; n=14\right)$.

When comparing the $\mathrm{OC}$ concentration with the mineral surface area in individual sediment layers, we found a weak positive relationship (Fig. 3A). On the other hand, we did not find a relationship between $\mathrm{OC} \mathrm{BE}$ and mean MSA for our 27 different sediment sites (linear regression $R^{2}=0.06$; $p=0.24$; Fig. 3B), indicating that MSA is not an important regulator of $\mathrm{OC} \mathrm{BE}$ in the studied sediments.

No distinct relationship between latitude and $\mathrm{OC} \mathrm{BE}$ was observed in our data set (data not shown). However, we found that the annual mean bottom water temperature was positively related to $\mathrm{OC}$ mineralization in lake sediments, in particular in the range of $3^{\circ} \mathrm{C}$ to $10^{\circ} \mathrm{C}$ (Fig. 4), and thereby negatively related to $\mathrm{OC} \mathrm{BE} \mathrm{(Fig.} \mathrm{1).}$

The OC BE was calculated from $\mathrm{OC}$ burial and $\mathrm{OC}$ mineralization, which in turn were calculated from several different parameters (see Methods). Our data showed that the magnitude of OC BE was most strongly influenced by OC burial, which in turn was most strongly influenced by the sedimentation rate (Fig. 1). The sedimentation rate alone explained $67 \%$ of the variability in OC BE (Fig. 5; $\mathrm{OC} \mathrm{BE}=32.1+27.9 \times \log ($ sedimentation rate $) ; R^{2}=0.67$; $p<0.0001 ; n=27)$.

\section{Discussion}

Organic carbon burial efficiency in lake sediments Our results show that in many lake sediments, OC burial efficiency is high (mean 48\%). This applies particularly to sediments receiving significant input of allochthonous matter, where average $\mathrm{OC} \mathrm{BE}$ was $66 \%$. In sediments that are predominantly composed of autochthonous matter, on the other hand, average $\mathrm{OC} \mathrm{BE}$ was $22 \%$. These average values only reflect a qualitative trend due to the limited amount of data, and because autochthonous and allochthonous sediments were distinguished qualitatively based on the published literature. The $\mathrm{C}: \mathrm{N}$ ratio, which is frequently used as a quantitative indicator of organic matter source, was not found to be related to the $\mathrm{OC}$ burial efficiency in the present analysis (Fig. 1). This could possibly be attributable to the very large differences between the studied sediments in terms of organic matter sources, degradation pathways, and microbial decomposers, all of which may affect the $C: N$ ratio in different ways. This implies that in a cross-system comparison of very different sediments, the $\mathrm{C}: \mathrm{N}$ ratio may not be a reliable indicator of organic matter source. Furthermore, $50 \%$ of the $\mathrm{C}: \mathrm{N}$ ratio data were within a narrow interval (9.9 11.4), potentially occluding any statistical effect of the $\mathrm{C}: \mathrm{N}$ ratio. Nevertheless, the large difference in mean $\mathrm{OC} \mathrm{BE}$ between different organic matter sources illustrates that allochthonous inputs to lake sediments stimulate OC burial and hamper OC mineralization. Further, these data indicate that the fate of allochthonous organic matter in lake sediments is primarily burial. Autochthonous organic matter, on the other hand, is less prone to burial and, consequently, primarily fuels microbial respiration in the sediments. Based on a very diverse data set (Table 1), these conclusions are most probably valid for lake sediments in general. Overall, our data show that roughly half of the OC deposited on lake floors may be buried in the sediments, illustrating that lakes are important modifiers of carbon export from the continents to the ocean, and highlighting the role of lake sediments as significant sinks in the global carbon cycle (Cole et al. 2007).

The effect of oxygen exposure time on organic carbon burial efficiency The OC burial efficiency was found to be strongly negatively related to the oxygen exposure time (Fig. 2). While the lake sediments derived from mainly autochthonous sources followed a similar trend as marine sediments (Hartnett et al. 1998), the OC BE in lake sediments derived from mainly allochthonous sources had a much stronger response to changes in OET (Fig. 2). Of the 27 different sediments in the present data set, there were only two exceptions to this pattern, both in Lake Kinneret. The sediment in the inflow area of the Jordan River (KIIN) had a comparatively low OC BE (Fig. 2). Possibly, the allochthonous inputs from the river to this sediment are diluted by the deposition of autochthonous matter derived from the high phytoplankton production in this eutrophic lake (Ostrovsky and Yacobi 1999). Further, this site is shallow (7-m depth), and the oscillating redox conditions in the top sediment probably result in frequent sediment mixing, which may significantly promote OC mineralization (Hulthe et al. 1998). On the other hand, OC BE in the central basin of Lake Kinneret (KI-C) was comparatively high (Fig. 2), given that the main OC source is autochthonous material (Ostrovsky and Yacobi 1999). However, lateral transport of sediment from shallow to deeper areas (i.e., focusing) is a significant process in Lake Kinneret due to the frequent and regular occurrence of strong internal 


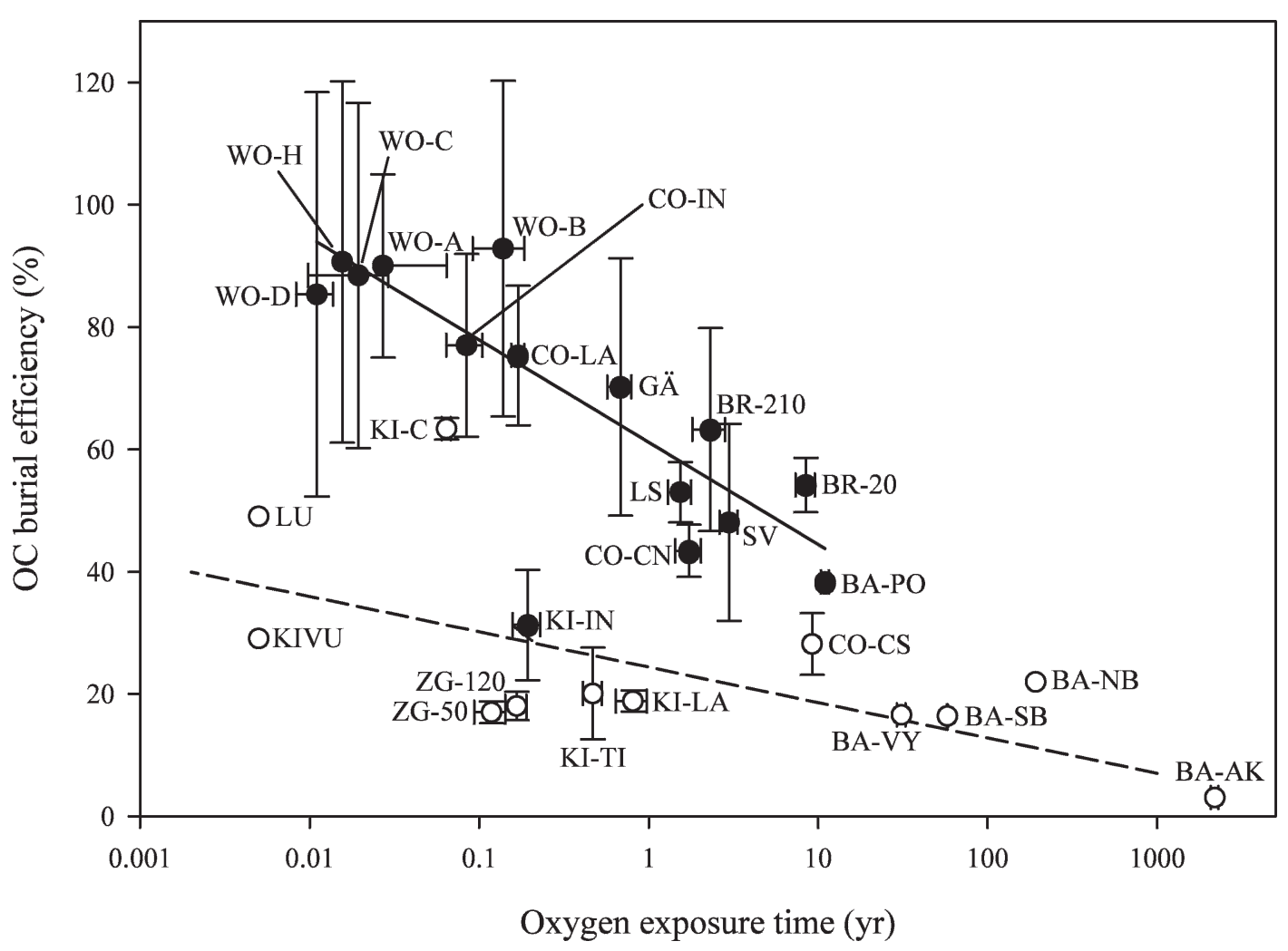

Fig. 2. Plot of oxygen exposure time against OC burial efficiency for the 27 different lake sediments. Open circles represent sites receiving sediment from mainly autochthonous sources; closed circles represent sites receiving sediment from mainly allochthonous sources. The solid line shows the linear regression for mainly allochthonous sediments (closed circles), excluding KI IN (see Discussion): $\mathrm{OC} \mathrm{BE}=61.216 .7 \times \log (\mathrm{OET}) ; R^{2}=0.81 ; p<0.0001 ; n=14$. The dashed line gives the relationship for marine sediments according to Hartnett et al. (1998). Linear regression for the mainly autochthonous sediments (open circles, excluding KI C; see Discussion) returns OC BE $=23.34 .39 \times \log (\mathrm{OET}) ; R^{2}=0.49 ; p<0.05 ; n=12$ (line not shown for clarity). The error bars show the $95 \%$ confidence interval; for some of the literature data, no error bars could be calculated. Maximum OC burial efficiency is $100 \%$, even though some confidence intervals exceed $100 \%$ mathematically. Abbreviations are as in Table 1.

waves. Hence, sediment at KIN-C has a relatively long predepositional history and is consequently relatively degraded (Ostrovsky and Yacobi 1999), which may help to explain the high $\mathrm{OC} \mathrm{BE}$ at this site.

Apart from these exceptions, our data show that allochthonous inputs to lake sediments both trigger a high $\mathrm{OC} \mathrm{BE}$, and result in a greater sensitivity of the OC toward oxic degradation. This effect is most likely due to the organic matter characteristics and not the mineral phase characteristics of the imported allochthonous matter. The lack of a positive relationship between $\mathrm{OC} B \mathrm{BE}$ and mineral surface area in lake sediments (Fig. 3B) indicates that mineral phase properties have subordinate importance for OC burial in lake sediments. Further, enhanced OC burial efficiency in allochthonous sediments is both observed in mineral-poor sediments with slow sedimentation rates (e.g., boreal lakes), and in mineral-rich sediments with high sedimentation rates (e.g., Brienz, Constance-inflow, Wohlen; Table 1; Figs. 2, 5). This strongly suggests that the high OC BE in allochthonous sediments is not primarily caused by a high rate of sedimentation of mineral particles per se, but rather by the recalcitrance of allochthonous organic matter.

Several studies have shown that while the degradation of autochthonous OC is independent of oxygen availability, the less reactive allochthonous $\mathrm{OC}$ is mineralized much faster under oxic than under anoxic conditions (Kristensen et al. 1995; Hulthe et al. 1998; Bastviken et al. 2004b). First, allochthonous OC is generally older than autochthonous OC (Mollenhauer and Eglinton 2007) and has consequently to a higher degree been exposed to predepositional degradation and transformation processes. Second, allochthonous OC is typically rich in molecules that are relatively resistant to anaerobic oxidation, e.g., longchained aliphatics, lignin, and humic matter (Zehnder and Svensson 1986; Emerson and Hedges 1988). Only in the presence of molecular oxygen can this aged, structurally complex allochthonous OC be exposed to the powerful attack by oxygenases (synthesized by aerobic bacteria) and by reactive oxygen species such as $\mathrm{H}_{2} \mathrm{O}_{2}$ and radical intermediates (Zehnder and Svensson 1986; Stumm and Morgan 1996). Furthermore, the activity of phenol oxidase is strongly inhibited under anoxic conditions, leading to an enrichment in phenolic compounds that in turn inhibit organic matter degradation by hydrolases (Freeman et al. 2001). Hence, the primary attack of the OC is comparatively weaker in the absence of oxygen, which may represent the rate-limiting step of the degradation of allochthonous $\mathrm{OC}$ in lake sediments. Intriguingly, even 

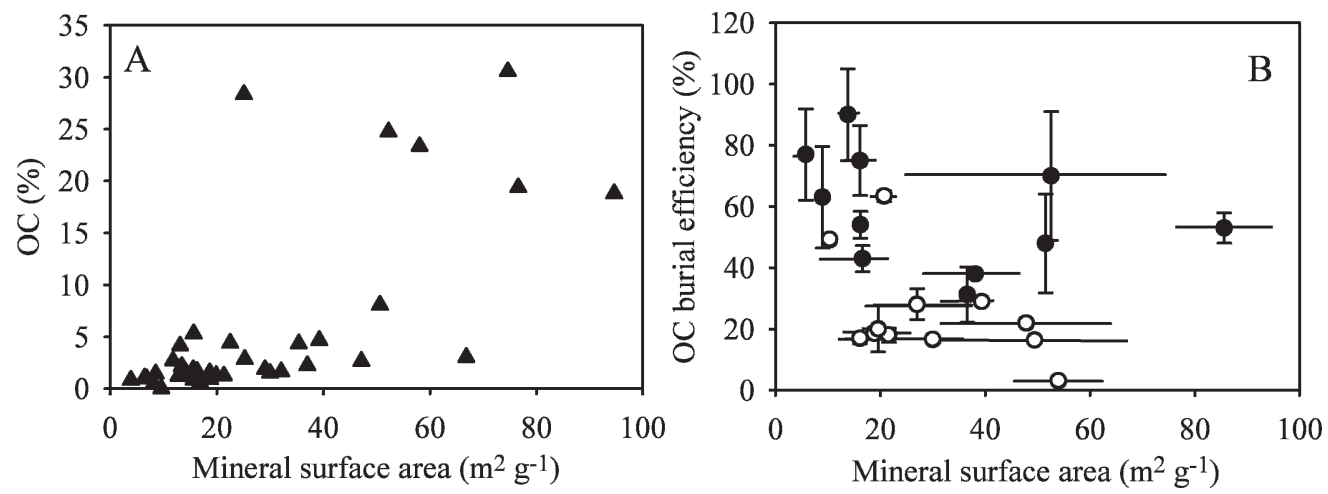

Fig. 3. (A) Relationship between mineral surface area and OC for individual sediment layers in the different lake sediments. (B) Mineral surface area against OC burial efficiency in different lake sediments. Open circles represent sites receiving sediment from mainly autochthonous sources; closed circles represent sites receiving sediment from mainly allochthonous sources. The points show the mean, vertical error bars show the $95 \%$ confidence interval, and horizontal bars show the range of mineral surface area in each sediment core.

the OC of ancient sediments (kyr Myr) can readily be mineralized by aerobic bacteria if re-exposed to oxygen (Moodley et al. 2005; Schillawski and Petsch 2008). To conclude, the greater effect of OET on the fate of $\mathrm{OC}$ in lake sediments with a high proportion of allochthonous compounds may be attributed to the restricted mineralization of allochthonous OC under anoxic conditions.

The absence of a mineral surface area effect on organic carbon burial efficiency No positive relationship was observed between the $\mathrm{OC} \mathrm{BE}$ and the mineral surface area (Fig. 3B), although such a correlation could have been expected based on frequent reports on the importance of protective mineral sorption for OC preservation in marine sediments (Keil et al. 1994; Mayer 1994b; Rothman and Forney 2007). The lack of a MSA effect on OC BE may possibly be attributable to the relatively high organic matter loading of the mineral surfaces in many lake sediments. The OC:MSA ratio in our lake sediments was on average $1.7 \mathrm{mg} \mathrm{m}{ }^{2}$, as compared to a range of $0.51 \mathrm{mg}$ $\mathrm{m} 2$ frequently found in marine sediments (Mayer 1994b). Furthermore, we suspect that the large effect of OET on OC BE, in particular in sediments dominated by allochthonous substances, may result in a comparatively little effect of MSA on OC BE in lake sediments as opposed to marine sediments. Hence, in spite of the obvious fact that organic matter sorbs onto mineral surfaces also in lake sediments, the frequently high organic matter loading, as well as the pronounced importance of OET, may mask a potential role of MSA in regulating the $\mathrm{OC} \mathrm{BE}$ in the present analysis.

Relationships of organic carbon burial efficiency with other variables Contrary to the study of the earth's large lakes by Alin and Johnson (2007), our data did not indicate a positive relationship between OC BE and latitude (not shown). Notably, Alin and Johnson (2007) defined the OC $\mathrm{BE}$ as the ratio between $\mathrm{OC}$ burial and primary production, while in the present study, OC BE is defined as the ratio between OC burial and OC deposition onto the sediment.
A direct comparison of $\mathrm{OC} \mathrm{BE}$ in the present study and the one by Alin and Johnson (2007) is therefore not possible.

We observed a negative relationship between annual mean bottom water temperature and OC BE (Fig. 1). Closer examination of this relationship shows that OC mineralization was positively related to annual mean bottom water temperature in the $310^{\circ} \mathrm{C}$ interval (Fig. 4), as observed in hypolimnetic sediments of mono- and dimictic lakes. Although the relationship is not very strong, it is in accordance with Den Heyer and Kalff (1998), who showed that mineralization rates in lake sediments are sensitive to temperature. The flattening of the relationship toward higher temperatures may partially be related to seasonally and permanently anoxic bottom waters in two of the five warmwater sites (Kinneret central and Kivu), potentially resulting in comparatively low mineralization rate at these sites.

We further found that water depth was weakly negatively related to OC BE (Fig. 1). This relationship is probably attributable to two effects. First, annual mean bottom water temperatures are generally colder in deep lakes than in shallow lakes, and this hampers mineralization and therefore triggers OC BE (Fig. 4). Second, OC degradation rates decrease exponentially with increasing $\mathrm{OC}$ age (Middelburg et al. 1993), implying that degradation rates may be higher for sinking particles, which are comparatively young, compared to sediments, which are comparatively old. Accordingly, sediment trap studies at a 1400-m-deep site in Lake Baikal showed that about $30 \%$ of the particulate OC sinking out of the mixed surface layer is mineralized during sinking to the sediment surface (Müller et al. 2005). Hence, it is likely that predepositional degradation in the water column is more intense for deeper lakes. High predepositional degradation reduces $\mathrm{OC}$ deposition on the sediment surface, and consequently stimulates $\mathrm{OC} \mathrm{BE}$ as defined here.

Predictability of organic carbon burial efficiency The PLS model (Fig. 1) explained 68\% of the variability in OC BE, and it had a high predictive power $\left(Q^{2}=0.69\right)$. However, the PLS model is based on many variables, several of which are not 


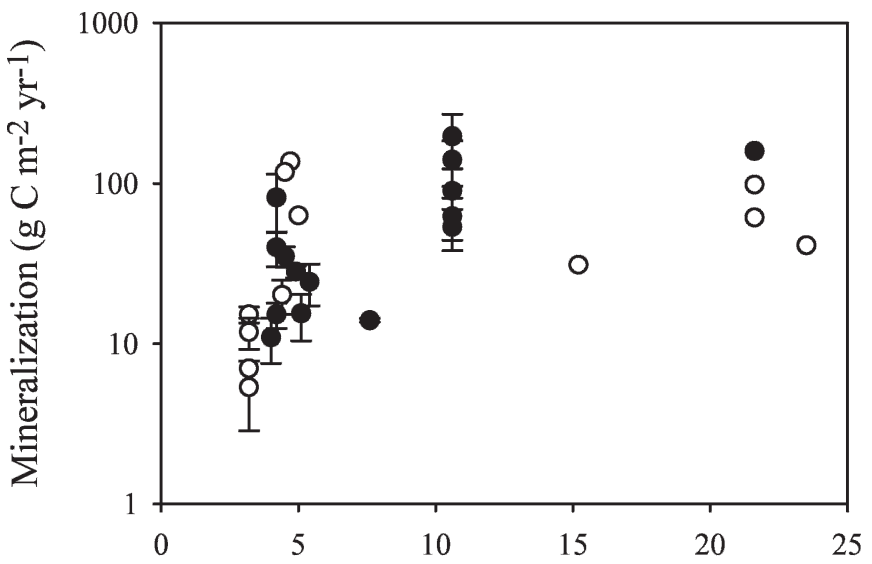

Annual mean bottom water temperature $\left({ }^{\circ} \mathrm{C}\right)$

Fig. 4. Relationship between the annual mean bottom water temperature and the OC mineralization in the different lake sediments. Open circles represent sites receiving sediment from mainly autochthonous sources; closed circles represent sites receiving sediment from mainly allochthonous sources. Error bars show the $95 \%$ confidence interval.

easily assessed. Our analysis shows that the sedimentation rate alone explained $67 \%$ of the variability in OC BE (Fig. 5). Hence, the sedimentation rate is the statistically most important predictor of OC burial efficiency in our data set. However, it is not evident what kind of mechanism could link the yearly increase in sediment thickness to the extent of OC mineralization or preservation; instead, we attribute the high predictive power of sedimentation rate to the fact that it is the most important factor in the calculation of OET and OC burial, which in turn can be mechanistically linked to the OC burial efficiency. As illustrated by the confidence bands of the regression line in Fig. 5, there is considerable uncertainty in the regression slope, as well as great deviations from the regression line for some of the sediments. Hence, predictions of OC BE from the sedimentation rate may suffer from a lack of accuracy. Inclusion of other easily available data (water temperature, water column depth) into a multiple linear regression model did not contribute significant additional explanatory power. However, an analysis of the residuals of the linear regression between the sedimentation rate and OC BE (Fig. 5) revealed that $75 \%$ of the positive residuals were associated with sediments dominated by allochthonous inputs, while $82 \%$ of the negative residuals were associated with sediments dominated by autochthonous inputs. This difference in residual direction between allochthonous and autochthonous sediments was statistically significant ( $t$-test, $t$ $=2.78, \mathrm{df}=25, p=0.010$ ), implying that allochthonous sediments tend to have a higher OC BE at a certain sedimentation rate, while autochthonous sediments tend to have a lower $\mathrm{OC} \mathrm{BE}$ at a certain sedimentation rate. It is therefore likely that quantitative information on the source of the sediment (autochthonous vs. allochthonous) will greatly enhance the predictability of OC BE in lake sediments.

Comparison with marine sediments The average OC BE in the studied lake sediments (48\%) was considerably higher than the average $\mathrm{OC} \mathrm{BE}$ for different marine sediments

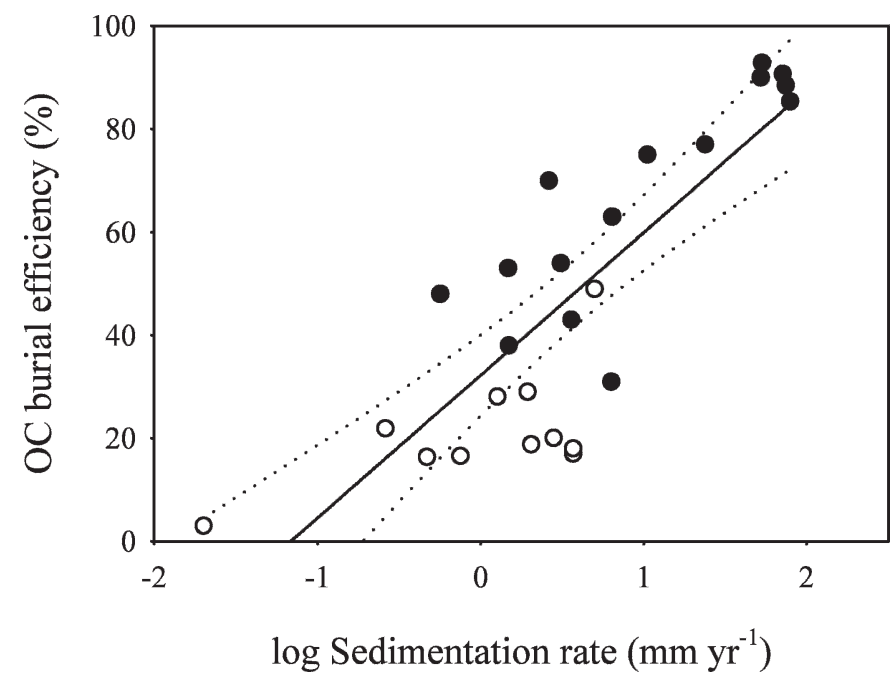

Fig. 5. Relationship between the OC burial efficiency and the sedimentation rate. The solid line shows the linear regression: $\mathrm{OC} \mathrm{BE}=32.1+27.9 \times \log ($ sedimentation rate $) ; R^{2}=0.67 ; p<$ $0.0001 ; n=27$. Open circles represent sites receiving sediment from mainly autochthonous sources; closed circles represent sites receiving sediment from mainly allochthonous sources. The dashed lines show the $95 \%$ confidence bands.

(29\%; Burdige 2007). The range in OC BE in the studied lake sediments, however, was similar to that found in marine sediments (Burdige 2007), except that very low OC BEs $(<3 \%)$ were absent in the lake sediments. Also, the ranges of OET and MSA in the studied lake sediments were comparable to marine sediments (Mayer 1994a,b; Hartnett et al. 1998). Since the gradients in OC BE, OET, and MSA are similar in lake and marine sediments, the potential mechanisms regulating OC BE may be compared.

In marine sediments, both OET and MSA were found to be related to OC burial and OC BE (Keil et al. 1994; Hartnett et al. 1998), while in lake sediments, our data suggest a major role of OET and allochthonous OC, and a minor role of MSA for OC BE (Figs. 2, 3). However, there are indications that the mechanisms regulating $\mathrm{OC} \mathrm{BE}$ in lake and marine sediments are fundamentally similar. Short OET and high allochthonous OC inputs do not only trigger high OC BE in lake sediments, but were also reported to give rise to the very high OC BE values in sediments of the Bengal Fan in the Indian Ocean (Galy et al. 2007). Further, allochthonous organic matter in the ocean is to a far greater extent prone to burial in the sediments than autochthonous organic matter (Burdige 2007), similar to lake sediments (this study). Also, if lake sediments resemble open-ocean sediments (long OET and mainly autochthonous $\mathrm{OC}$ ), they display $\mathrm{OC} \mathrm{BE}$ values similar to open-ocean sediments (e.g., BA-AK, 3\%). The main difference in the geochemistry of marine and freshwater sediments is the concentration of sulfate. Because it is the rate of fermentation that kinetically limits both sulfate reduction and methanogenesis (Postma and Jakobsen 1996), the difference in sulfate concentration should not result in a different extent of overall OC mineralization in marine vs. freshwater sediments. From this point of view, it makes sense that the mechanisms regulating $\mathrm{OC} \mathrm{BE}$ in marine and freshwater sediments appear to be similar. 
Hence, we propose that for both marine and freshwater sediments, the specific characteristics in terms of OET, mineral surface area, and organic matter source will determine the different mechanisms that will be the most important regulator of $\mathrm{OC} \mathrm{BE}$. Lakes receive frequently high inputs of allochthonous OC (Sobek et al. 2007), and the OET tends to be shorter in lake sediments (Fig. 2) than in open-ocean sediments (Hartnett et al. 1998). Hence, OC source and OET have a comparatively large influence on OC $\mathrm{BE}$ in lake sediments. Open-ocean sediments receive mainly autochthonous $\mathrm{OC}$, and the OET is in most cases longer than in lake sediments. Therefore, the effect of OC source and OET may be moderate in open-ocean sediments, and the protective sorption of potentially bioavailable autochthonous OC on mineral surfaces may be more important (Keil et al. 1994). To conclude, the high average OC BE in lake as compared to marine sediments is probably attributable to the frequently sizable allochthonous $\mathrm{OC}$ inputs to lakes, as well as to the frequent occurrence of suboxic conditions in bottom waters of lakes.

Effects of environmental change on organic carbon burial efficiency and methanogenesis OC burial in lake sediments is an important sink in the global carbon cycle (Dean and Gorham 1998). Likewise, methanogenesis in lake sediments constitutes an important source of atmospheric methane (Bastviken et al. 2004a). Thus, lake sediments are important players in the global carbon cycle because they are able to act as both a sink and a source. Our analysis shows that the relative proportions of allochthonous OC and autochthonous OC, in concert with the oxygen exposure time, largely determine if the deposited $\mathrm{OC}$ is buried or mineralized (Fig. 2). Also, the bottom water temperature had a discernible effect on $\mathrm{OC}$ mineralization, and thus $\mathrm{OC} \mathrm{BE}$ (Fig. 4). The proportion of different OC sources, oxygen availability, and temperature is dependent on environmental conditions. Hence, it is evident that environmental change will affect the role of lake sediments in the carbon cycle.

Eutrophication increases the input of autochthonous OC to the sediment, which is to a far greater extent mineralized than buried in the sediments. Oxygen consumption during OC mineralization leads to anoxic bottom waters, which is typically observed in eutrophic stratified lakes. As anoxic conditions do not impede the degradation of autochthonous OC (Kristensen et al. 1995), eutrophication thereby stimulates methanogenesis in hypolimnetic sediments. While methane diffusing out of the sediment will probably be oxidized, methane ebullition could, dependent on water-column depth, result in the emission of methane from the lake to the atmosphere (McGinnis et al. 2006). Hence, if a lake is subject to eutrophication, the $\mathrm{OC} \mathrm{BE}$ is likely to decrease, but the methane emission to the atmosphere is likely to increase.

Climate change has the capacity to alter terrestrial vegetation, soils, and hydrology, and it can thus modify the export of OC from catchments to lakes. The increased terrestrial OC export reported from some regions (e.g., northern Europe) has resulted in a concomitant increase in the sedimentation of allochthonous OC in lakes (Von Wachenfeldt et al. 2008). Increased allochthonous OC input to the sediments has probably resulted in a higher OC BE in the lakes of such regions. In regions where terrestrial OC export has decreased (e.g., Ontario; Schindler et al. 1997), the $\mathrm{OC} \mathrm{BE}$ in lake sediments has probably been reduced.

Climate change will further alter the thermal properties of lakes; while surface waters are expected to experience substantial heating, hypolimnetic waters will probably only warm moderately or not at all (De Stasio et al. 1996). This has two implications with respect to the fate of sediment OC. On one hand, higher epilimnetic temperatures will promote $\mathrm{OC}$ mineralization, and thereby reduce $\mathrm{OC} \mathrm{BE}$, in epilimnetic sediments (Fig. 4). On the other hand, an increased temperature difference between epilimnetic and hypolimnetic waters implies prolonged periods of stratification, which in turn have the potential to greatly increase the oxygen deficiency in bottom waters (Jankowski et al. 2006). The strong relationship between OC BE and OET (Fig. 2) suggests that an increasing hypolimnetic oxygen deficiency would result in a concomitant increase in the OC $\mathrm{BE}$ of hypolimnetic sediments in the future.

Further, prolonged anoxia will not only stimulate OC burial, but it will also stimulate methanogenesis. We tested the potential stimulation of methanogenesis as a result of oxygen deficiency by combining data from this study with data from meso- to hypereutrophic lakes and reservoirs in Finland (Huttunen et al. 2006). We found that with decreasing oxygen penetration depth into the sediment, diffusive $\mathrm{CH}_{4}$ flux from the sediment increased (Fig. 6). Even if the relationship was weak $\left(R^{2}=0.28\right)$, the regression slope was significantly different from zero $(p=$ 0.023 ), illustrating the negative coupling between oxygen availability and methane flux from the sediment in a very diverse set of sediments. Hence, prolonged anoxia will not only trigger increased $\mathrm{OC} \mathrm{BE}$, but it will at the same time give rise to increased methane emission from the sediment. Given this whole array of potential climate-change effects on $\mathrm{OC} \mathrm{BE}$, it is not possible to gauge the net feedback to climate change with any certainty. However, due to the $\sim 20$-fold greater global warming potential of $\mathrm{CH}_{4}$ as compared to $\mathrm{CO}_{2}$, it takes only a very little increase in methane emission to offset any potential future increase of the OC sink in lake sediments.

The high OC BE, particularly of allochthonous OC, in lake sediments illustrates the importance of lakes as modifiers of carbon export from land to sea. As the mean OC BE for allochthonous lake sediments was $66 \%$, we may infer that, on average, on the order of two thirds of the allochthonous OC deposited onto lake sediment is buried. The remainder is mineralized to $\mathrm{CO}_{2}$ and $\mathrm{CH}_{4}$ and may eventually reach the atmosphere. In that respect, lake sediments could not only act as OC sinks, but they could also act as transformers of terrestrial organic carbon to atmospheric $\mathrm{CO}_{2}$ and $\mathrm{CH}_{4}$. This is particularly important in the case of methane because the transformation of $\mathrm{OC}$ to $\mathrm{CH}_{4}$ along the flow path from land to sea is largely confined to lake sediments. The channeling of $\mathrm{OC}$ into burial carbon dioxide or methane is dependent on the OC source, oxygen exposure time, and temperature, all of which are sensitive to environmental change (eutrophication and climate change). While the present study demonstrates that environmental change will substantially 


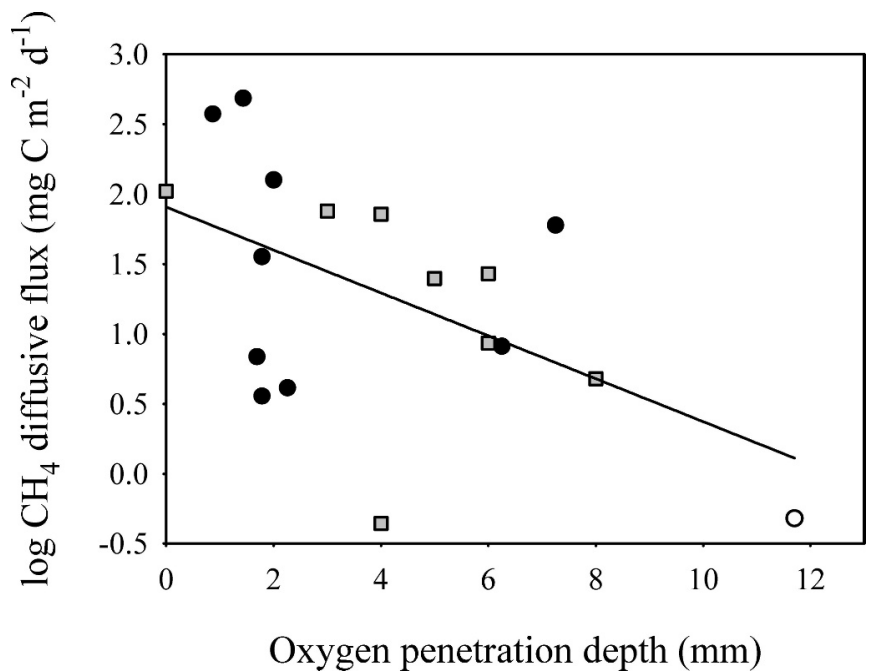

Fig. 6. The relationship between oxygen penetration depth into the sediment and diffusive $\mathrm{CH}_{4}$ flux from the sediment to the water column. Circles represent data from this study (Swedish boreal lakes, Lake Constance, Lake Wohlen); the open circle represents a site receiving sediment from mainly autochthonous sources, and the closed circles represent sites receiving sediment from mainly allochthonous sources. The gray squares show data from eight meso and hypereutrophic lakes and reservoirs in Finland (Huttunen et al. 2006). The solid line represents a linear regression for all data in the plot $\left(\log \mathrm{CH}_{4}\right.$ flux $=1.91 \quad 0.15 \times$ oxygen penetration; $R^{2}=0.28 ; p<0.05 ; n=18$ ).

affect the OC BE of lake sediments, further studies are needed in order to quantify the overall effect of environmental changes on $\mathrm{OC} \mathrm{BE}$.

\section{Acknowledgments}

We thank Andreas Brand, Jakob Frommer, Cristian Gudasz, Lucia Klauser, Ilia Ostrovsky, Tonya del Sontro, Michael Schurter, and Alois Zwyssig for help with sampling and analyses, and Beat Müller, Martin Märki, and Michael Sturm for sharing data and sediment samples. This study was supported by the Swiss National Science Foundation (grants 200021112274 and 200020 120112).

\section{References}

Albrecht, A., R. Reiser, A. Luck, J. M. A. Stoll, and W. Giger. 1998. Radiocesium dating of sediments from lakes and reservoirs of different hydrological regimes. Environ. Sci. Technol. 32: 18821887.

Alin, S., And T. C. Johnson. 2007. Carbon cycling in large lakes of the world: A synthesis of production, burial, and lake atmosphere exchange estimates. Glob. Biogeochem. Cycles 21: GB3002, doi: 10.1029/2006GB002881.

Al Mutlaq, K. F., L. J. Standley, and B. R. T. Simoneit. 2008. Composition and sources of extractable organic matter from a sediment core in Lake Kivu, East African rift valley. Appl. Geochem. 23: 10231040.

Archer, D., S. Emerson, and C. R. Smith. 1989. Direct measurement of the diffusive sublayer at the deep sea floor using oxygen microelectrodes. Nature 340: 623626.

Bastviken, D., J. J. Cole, M. L. Pace, and L. J. Tranvik. $2004 a$. Methane emissions from lakes: Dependence of lake character istics, two regional assessments, and a global estimate. Glob. Biogeochem. Cycles 18: GB4009, doi: 10.1029/2004GB002238.
, L. Persson, G. Odham, and L. J. Tranvik. $2004 b$. Degradation of dissolved organic matter in oxic and anoxic lake water. Limnol. Oceanogr. 49: 109116.

Brunauer, S., P. H. Emmett, And E. Teller. 1938. Adsorption of gases in multimolecular layers. J. Am. Chem. Soc. 60: 309319.

Burdige, D. J. 2007. Preservation of organic matter in marine sediments: Controls, mechanisms, and an imbalance in sediment organic carbon budgets? Chem. Rev. 107: 467485.

Cole, J. J., AND others. 2007. Plumbing the global carbon cycle: Integrating inland waters into the terrestrial carbon budget. Ecosystems 10: 171184.

Cranwell, P. A. 1981. Diagenesis of free and bound lipids in terrestrial detritus deposited in a lacustrine sediment. Org. Geochem. 3: 7989.

Dean, W. E., and E. Gorham. 1998. Magnitude and significance of carbon burial in lakes, reservoirs, and peatlands. Geology 26: 535538 .

Demaison, G. J., and G. T. Moore. 1980. Anoxic environments and oil source bed genesis. Org. Geochem. 2: 931.

Den Heyer, C., AND J. KalfF. 1998. Organic matter mineraliza tion rates in sediments: A within and among lake study. Limnol. Oceanogr. 43: 695705.

De Stasio, B. T. J., D. K. Hill, J. M. Kleinhans, N. P. Nibbelink, and J. J. Magnuson. 1996. Potential effects of global climate change on small north temperate lakes: Physics, fish, and plankton. Limnol. Oceanogr. 41: 11361149.

Downing, J. A., J. J. Cole, J. J. Middelburg, R. G. Striegl, C. M. Duarte, P. Kortelainen, Y. T. Prairie, and K. A. Laube. 2008. Sediment organic carbon burial in agriculturally eutrophic impoundments over the last century. Glob. Biogeo chem. Cycles 22: GB1018, doi: 10.1029/2006GB002854.

Emerson, S. R., And J. I. Hedges. 1988. Processes controlling the organic carbon content of open ocean sediments. Paleocea nography 3: 621634.

Freeman, C., N. Ostle, and H. Kang. 2001. An enzymatic 'latch' on a global carbon store. Nature 409: 149.

Galy, V., C. France Lanord, O. Beyssac, P. Faure, H. Kudrass, and F. PAlHol. 2007. Efficient organic carbon burial in the Bengal fan sustained by the Himalayan erosional system. Nature 450: 407410.

Gelinas, Y., J. A. Baldock, and J. I. Hedges. 2001. Organic carbon composition of marine sediments: Effect of oxygen exposure on oil generation potential. Science 294: 145148.

GranÉli, H. W. 1979. A comparison of carbon dioxide production and oxygen uptake in sediment cores from four south Swedish lakes. Holarctic Ecol. 2: 5157.

HÅKanson, L. 2003. Quantifying burial, the transport of matter from the lake biosphere to the geosphere. Int. Rev. Hydro biol. 88: 539560 .

Hartnett, H. E., R. G. Keil, J. I. Hedges, and A. H. Devol. 1998. Influence of oxygen exposure time on organic carbon preserva tion in continental margin sediments. Nature 391: 572574.

Hedges, J. I., F. S. Hu, A. H. Devol, H. E. Hartnett, E. Tsamakis, And R. G. KeIL. 1999. Sedimentary organic matter preservation: A test for selective degradation under oxic conditions. Am. J. Sci. 299: 529555.

Ho, E. S., And P. A. Meyers. 1994. Variability of early diagenesis in lake sediments evidence from the sedimentary geolipid record in an isolated tarn. Chem. Geol. 112: 309324.

Hofmann, A. 1996. Geochemical characteristics and processes of particulate matter transport in the north basin of Lake Lugano (Switzerland, Italy). Ph.D. thesis. University of Geneva (written in French).

Hoskuldsson, A. 1988. PLS regression methods. J. Chemometr. 2: 211228. 
Hulthe, G., S. Hulth, and P. O. J. Hall. 1998. Effect of oxygen on degradation rate of refractory and labile organic matter in continental margin sediments. Geochim. Cosmochim. Acta 62: 13191328.

Huttunen, J. T., T. S. Vaisanen, S. K. Hellsten, and P. J. MartikAinen. 2006. Methane fluxes at the sediment water interface in some boreal lakes and reservoirs. Boreal Environ. Res. 11: 2734.

IPCC. 2007. Climate change 2007: The physical science basis. Contribution of Working Group I to the Fourth Assessment Report of the Intergovernmental Panel on Climate Change. Cambridge Univ. Press.

Jankowski, T., D. M. Livingstone, H. Buhrer, R. Forster, And P. Niederhauser. 2006. Consequences of the 2003 European heat wave for lake temperature profiles, thermal stability, and hypolimnetic oxygen depletion: Implications for a warmer world. Limnol. Oceanogr. 51: 815819.

Keil, R. G., D. B. Montlucon, F. G. Prahl, and J. I. Hedges. 1994. Sorptive preservation of labile organic matter in marine sediments. Nature 370: 549552.

Koren, N., And M. KLeIN. 2000. Rate of sedimentation in Lake Kinneret, Israel: Spatial and temporal variations. Earth Surf. Proc. Land. 25: 895904.

Kortelainen, P., H. Pajunen, M. Rantakari, and M. SaArnisto. 2004. A large carbon pool and small sink in boreal Holocene lake sediments. Glob. Change Biol. 10: 16481653.

Kristensen, E., S. I. Ahmed, and A. H. Devol. 1995. Aerobic and anaerobic decomposition of organic matter in marine sediment: Which is fastest? Limnol. Oceanogr. 40: 14301437.

Laskov, C., W. Amelung, and S. Peiffer. 2002. Organic matter preservation in the sediment of an acidic mining lake. Environ. Sci. Technol. 36: 42184223.

Lu, X. 2007. A note on removal of the compaction effect for the 210 Pb method. Appl. Radiat. Isotopes 65: 142146.

MARKI, M. 2007. Biogeochemical processes in surface sediments of lakes a microscale approach. Ph.D. thesis. Swiss Federal Institute of Technology Zurich (ETH).

, B. Muller, C. Dinkel, And B. Wehrli. 2009. Mineral ization pathways in lake sediments with different oyxgen and organic carbon supply. Limnol. Oceanogr. 54: 428438.

, AND B. Wehrli. 2006. Microscale mineralization pathways in surface sediments a chemical sensor study in Lake Baikal. Limnol. Oceanogr. 51: 13421354.

Martin, P., L. Granina, K. Martens, and B. Goddeeris. 1998. Oxygen concentration profiles in sediments of two ancient lakes: Lake Baikal (Siberia, Russia) and Lake Malawi (East Africa). Hydrobiologia 367: 163174.

Mayer, L. M. 1994a. Relationships between mineral surfaces and organic carbon concentrations in soils and sediments. Chem. Geol. 114: 347363.

1994b. Surface area control of organic carbon accumula tion in continental shelf sediments. Geochim. Cosmochim. Acta 58: 12711284.

1999. Extent of coverage of mineral surfaces by organic matter in marine sediments. Geochim. Cosmochim. Acta 63: 207215.

McGinnis, D. F., J. Greinert, Y. Artemov, S. E. Beaubien, and A. Wuest. 2006. Fate of rising methane bubbles in stratified waters: How much methane reaches the atmosphere? J. Geophys. Res. 111: C09007, doi: 10.1029/2005JC003183.

Meckler, A. N., C. J. Schubert, G. L. Cowie, S. Peiffer, And M. DitTRICH. 2004. New organic matter degradation proxies: Valid in lake systems? Limnol. Oceanogr. 49: 20232033.

Middelburg, J. J., T. Vlug, and F. Vandernat. 1993. Organic matter mineralization in marine systems. Glob. Planet. Change 8: 4758 .
Mollenhauer, G., and T. I. Eglinton. 2007. Diagenetic and sedimentological controls on the composition of organic matter preserved in California Borderland Basin sediments. Limnol. Oceanogr. 52: 558576.

Moodley, L., J. J. Middelburg, P. M. J. Herman, K. Soetaert, AND G. J. De LANGE. 2005. Oxygenation and organic matter preservation in marine sediments: Direct experimental evi dence from ancient organic carbon rich deposits. Geology 33: 889892.

Mulholland, P. J., And J. W. Elwood. 1982. The role of lake and reservoir sediments as sinks in the perturbated global carbon cycle. Tellus 34: 490499.

Muller, B., M. Marki, M. Schmid, E. G. Vologina, B. Wehrli, A. Wuest, ANd M. STuRm. 2005. Internal carbon and nutrient cycling in Lake Baikal: Sedimentation, upwelling, and early diagenesis. Glob. Planet. Change 46: 101124.

, AND OTHERS. 2007. Present and past bio available phosphorus budget in the ultra oligotrophic Lake Brienz. Aquat. Sci. 69: 227239.

Ostrovsky, I., AND Y. Z. YACOBI. 1999. Organic matter and pigments in surface sediments: Possible mechanisms of their horizontal distributions in a stratified lake. Can. J. Fish. Aquat. Sci. 56: 10011010.

Postma, D., AND R. JAKobSEN. 1996. Redox zonation: Equilibrium constraints on the $\mathrm{Fe}(\mathrm{III}) / \mathrm{SO}_{4}$ reduction interface. Geochim. Cosmochim. Acta 60: 31693175.

Rothman, D. H., And D. C. Forney. 2007. Physical model for the decay and preservation of marine organic carbon. Science 316: 13251328.

Schillawski, S., AND S. T. Petsch. 2008. Release of biodegradable dissolved organic matter from ancient sedimentary rocks. Glob. Biogeochem. Cycles 22: GB3002, doi: 10.1029/2007GB002980.

Schindler, D. W., P. J. Curtis, S. E. Bayley, B. R. Parker, K. G. Beaty, and M. P. Stainton. 1997. Climate induced changes in the dissolved organic carbon budgets of boreal lakes. Biogeochemistry 36: 928.

Sobek, S., L. J. Tranvik, Y. T. Prairie, P. Kortelainen, and J. J. ColE. 2007. Patterns and regulation of dissolved organic carbon: An analysis of 7,500 widely distributed lakes. Limnol. Oceanogr. 52: 12081219.

Stumm, W., And J. J. Morgan. 1996. Aquatic chemistry: Chemical equilibria and rates in natural waters, $3 \mathrm{rd}$ ed. Wiley Interscience.

Von Wachenfeldt, E., S. Sobek, D. Bastviken, and L. J. TrAnvik. 2008. Linking allochthonous dissolved organic matter and boreal lake sediment carbon sequestration the role of light mediated flocculation. Limnol. Oceanogr. 53: 24162426.

, AND L. TranviK. 2008. Sedimentation in boreal lakes the role of flocculation of allochthonous dissolved organic matter in the water column. Ecosystems 11: 803814.

Wessels, M. 1998. Late glacial and postglacial sediments in Lake Constance (Germany) and their palaeolimnological implica tions. Arch. Hydrobiol. Suppl. 53: 411449.

Westrich, J. T., AND R. A. Berner. 1984. The role of sedimentary organic matter in bacterial sulfate reduction: The $G$ model tested. Limnol. Oceanogr. 29: 236249.

Zehnder, A. J. B., AND B. H. Svensson. 1986. Life without oxygen what can and what cannot? Experientia 42: 11971205.

Associate editor: Bo Thamdrup

Received: 26 February 2009 Accepted: 26 June 2009 Amended: 28 July 2009 